\title{
APPLICATION OF ADSORPTION PROCESS FOR PHENOLIC COMPOUNDS REMOVAL FROM AQUEOUS ENVIRONMENTS: A SYSTEMATIC REVIEW
}

\author{
BAZRAFSHAN E. ${ }^{1}$ \\ AMIRIAN P. ${ }^{1, *}$ \\ MAHVI A.H. ${ }^{2,3}$ \\ ANSARI-MOGHADDAM A. ${ }^{1}$
}

\author{
Health Promotion Research Center \\ Zahedan University of Medical Sciences, Zahedan, Iran \\ ${ }^{2}$ School of Public Health \\ Tehran University of Medical Sciences, Tehran, Iran \\ ${ }^{3}$ Center for Solid Waste Research, Institute for Environmental Research \\ Tehran University of Medical Sciences, Tehran, Iran
}

Received: $21 / 06 / 2015$

Accepted: $16 / 01 / 2016$

Available online: $29 / 01 / 2016$

\begin{abstract}
Wastewater from various types of industries such as synthetic resins, plywood industries, paper and pulp, gas and coke oven plants, paints, coal gas, tanning, textile, plastic, rubber, pharmaceutical, petroleum and mine discharges, contain different types of phenols. Phenolic compounds are toxic substances and some are known or suspected carcinogens. Therefore it is important to remove phenol and phenolic compounds from contaminated industrial aqueous streams before discharged into any water bodies. Adsorption of phenol and its derivatives from aqueous solution by activated carbon is one of the most investigated of all liquid phase applications of carbon adsorbents. Several adsorbents have been used for treatment of wastewater and removal of phenolic compounds. Literature contains various adsorption processes and adsorbents such as pistachio nut shell ash, Moringa peregrina tree shell ash, agricultural fibers, red mud, low cost clay, olive mill waste, natural zeolites, rubber seed coat, peat, fly ash, bentonite and ... which have been used for the removal of phenol and its derivatives. Any of chemical, biological and physical treatment processes has its own advantages and disadvantages. It is worth mentioning that economic aspects of these processes are important, for example biosorption were found to be effective methods with scope for further research in this field in terms of cost effectiveness and regeneration. At present study various adsorbents used by the authors of this article and other researchers for phenol and its derivatives from aqueous environments have been reported and summarized. Additionally, more research is needed to find the practical utility of low-cost adsorbents on commercial scale.
\end{abstract}

Keywords: Phenol and phenolic compounds, aqueous environments, adsorption

\section{Introduction}

In recent years, increasing awareness of water pollution and its far reaching effects has prompted concerted efforts towards pollution abatement (Donmez et al., 1999). Contamination of aqueous environments by heavy metals and phenolic compounds is a worldwide environmental problem due to their toxic effects and accumulation through the food chain (Kapoor et al., 1999; Perez-Rama et al., 2002; Sternberg and Dorn, 2002). With regard to increasing effluent discharge standards to the environment, high considerations should be made when selecting proper treatment processes. Any of chemical, biological and physical treatment processes has its own advantages and disadvantages. Application of some waste products that could help in this regard, in addition to reuse of these waste materials, can be

Bazrafshan E., Amirian P., Mahvi A.H. and Ansari-Moghaddam A. (2016), Application of adsorption process for phenolic compounds removal from aqueous environments: a systematic review, Global NEST Journal, 18(1), 146-163. 
an advantage (Mahvi, 2008). Among the different organic pollutants in wastewater, phenolic compounds are considered as priority pollutants since they are harmful to plants, animals and human, even at low concentrations. The major sources of phenolic compounds are steel mills, petroleum refineries, pharmaceuticals, petrochemical, coke oven plants, paints, coal gas, synthetic resins, plywood industries and mine discharge. The wastewater with the highest concentration of phenol $\left(>1000 \mathrm{mg} \mathrm{l}^{-1}\right)$ is typically generated from coke processing. Phenolic compounds are also emanated from resin plants with a concentration range of $12-300 \mathrm{mg} \mathrm{l}^{-1}$. Environmental Protection Agency (EPA) has set a limit of $0.1 \mathrm{mg} \mathrm{l}^{-1}$ of phenol in the treated effluent in order to protect human health from the potential toxic effects caused by exposure to phenol (Balasubramanian and Venkatesan, 2012). The World Health Organization (WHO) is stricter on phenol regulation. It sets a $0.001 \mathrm{mg} \mathrm{l}^{-1}$ as the limit of phenol concentration in potable water (Radovic et al., 2001).Therefore, phenol is listed as a toxic substance and is included in the priority list of hazardous substances as well, which demonstrates its serious health and ecological effects (Busca et al., 2008). Phenol ranks in the top 50 in production volumes for chemicals produced in the United States (Ahmaruzzaman, 2008). Biological treatment (Li et al., 2011; Bajaj et al., 2008; Moussavi et al., 2010), coagulation and electrocoagulation (Bazrafshan et al., 2012a; Bazrafshan et al., 2012b), ultrasonic degradation (Mahvi, 2009; Maleki et al., 2007; Pandit et al., 2001), activated carbon adsorption and other adsorbents (Bazrafshan et al., 2012c; Zarei et al., 2013; Mahvi et al., 2004; Mohan and Chander, 2001; ElNaas et al., 2010; Dursun et al., 2005; Gurses and Yalcin, 2005), membrane filtration (Bodalo et al., 2009), enzymatic treatments (Mao et al., 2006), solvent extraction (Juang et al., 2010), photocatalytic degradation (Mahvi et al., 2007; Dianati-tilaki et al., 2014), chemical oxidation and electrochemical methods (Canizares et al., 2002; BelhadjTahara and Savall, 2009; Yavuz and Koparal, 2006), are the most widely used methods for removing phenol and phenolic compounds from wastewaters. Problems such as high expenses, low efficiency, and generation of toxic by-products are associated with the above methods (Nazari et al., 2007). Adsorption is a low cost and important physical process for the treatment and renovation of wastewater. It exploits the ability of certain solids to preferentially concentrate specific substance from solution onto their surfaces. In this manner, the component of either gases or liquid solutions can be separated from each other. Various non-conventional adsorbents like saw dust, bagasse pith, rice husk ash, activated coconut shell powder, controlled burnt wood charcoal, fly ash, peat, wood, jute fibers have been tried by the investigators (Kulkarni and Kaware, 2013). The parameters which have been investigated for optimizing the use of nonconventional adsorbents in wastewater treatment include nature of adsorbate and adsorbent, adsorbate concentration, adsorbent dose, contact time, $\mathrm{pH}$ of solution, particle size of adsorbent, thermodynamic parameters, etc. (Singh and Srivastava, 2002). The treatment with activate carbon, silicates and polymer resins are considered to be an effective method for the removal of phenol from wastewater because of its large surface area, micro porous nature, high adsorption capacity, high purity and ease of availability (Radeke et al., 1993). Phenol removal by adsorption process remains the best treatment of choice as it can generally remove all types of phenols in a simple and easy operation. The adsorbent that is used in practice remains activated carbon (Jung et al., 2001). However because of high cost of activated carbon, its usage is sometimes restricted due to economic considerations. As such, attempts have been made by many researchers to develop alternative adsorbents, preferably of low cost. Literature survey shows that a large number of alternative adsorbents have been studied to replace activated carbon. Both, the industrial wastes as well as some natural resource materials such as bentonite (Banat et al., 2000), olive mill waste (Abdelkreem, 2013), pistachio nut shell ash (Bazrafshan et al., 2012c), coconut shell (Kulkarni et al., 2013), rubber seed coat (Rengaraj et al., 2002b), Moringa peregrina seed extract (Bazrafshan et al., 2012a), rice husk and rice husk ash (Mahvi et al., 2004), avocado kernels (Rodrigues et al., 2011) have been utilized for this purpose. Recently interest has turned to using various biomasses and agricultural wastes as biosorbent, which have the advantage of low cost and increased tolerance of environmental conditions. Biosorption can be defined as a process in which solids of natural origin are employed for sequestration or separation of pollutants from an aqueous environment (Muraleedharan et al., 1991). Many natural materials were used as biosorbent for phenol removal, like wheat husk (Jagwani and Joshi, 2014) jute stick (Mustafa et al., 2008), tobacco residues (Kilic et al., 2011) and tamarind nutshell (Goud et al., 2005), presented with low cost viable options. In this article, the use of activated carbon and various low cost natural adsorbents for the 
removal of phenolic compounds from contaminated effluents has been reviewed, reported and evaluated. Instead of using commercial activated carbon, researchers have worked on inexpensive adsorbents such as bentonite, biomass, fly ash, zeolites and other natural materials, which have high adsorption capacity and are locally available.

\section{Adsorption of phenol and its derivatives}

In recent years literature surveys show that a large number of alternative adsorbents have been studied to replace activated carbon. The review presents the summary of the removal of phenol and its derivatives by using following adsorbents by investigators in research works (Table 1). Also the comparison of adsorption capacities for various phenolic compounds on adsorbents was shown in the Figure 1.

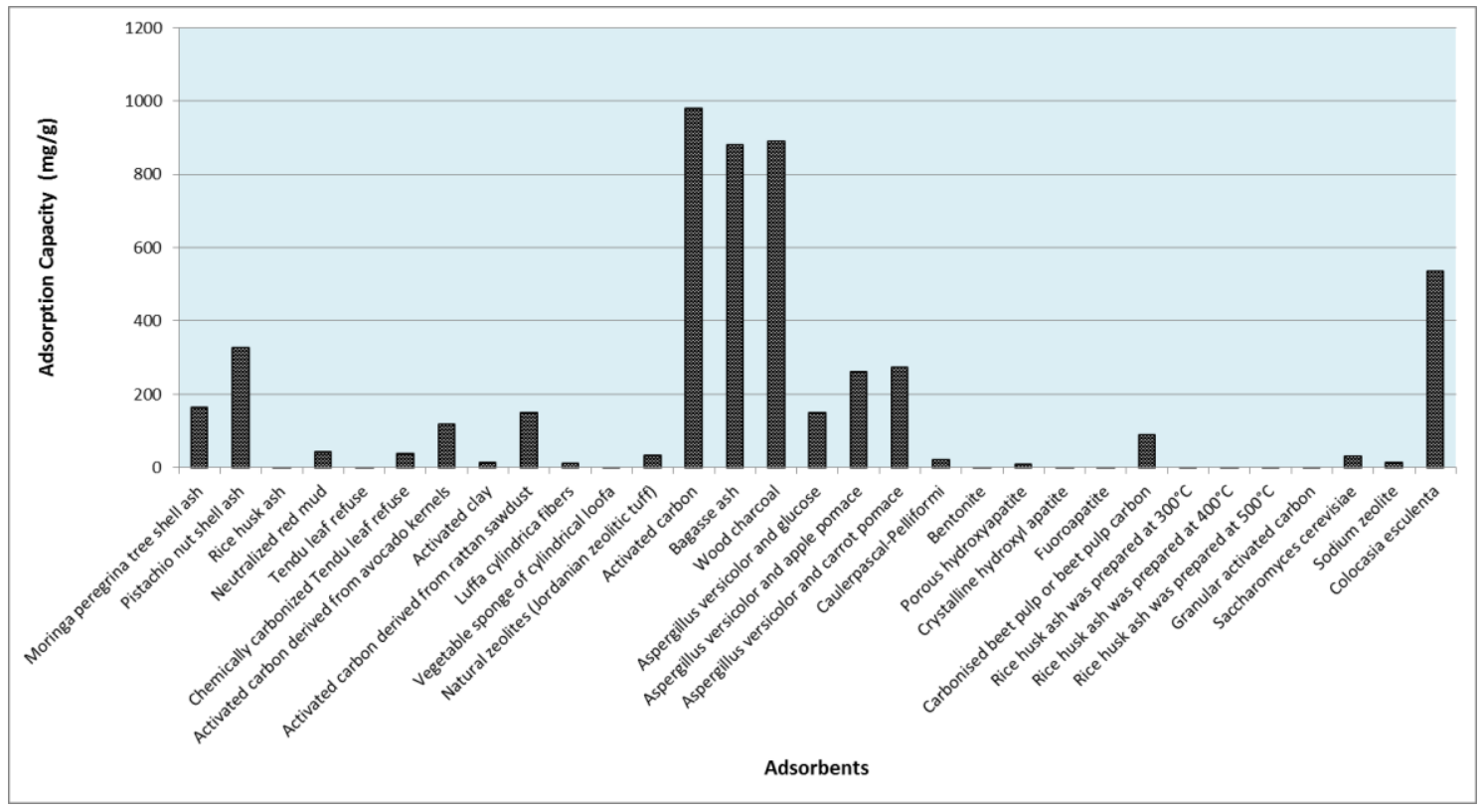

Figure 1. Comparison of adsorption capacities for phenolic compounds on various adsorbents

\section{Various adsorbents used for adsorption of phenol and its derivatives}

Zarei et al., (2013), studied the efficiency of Moringa peregrina tree shell ash for the removal of phenol from aqueous solutions; the examination was carried out in a batch system. According to the results of this study, it was found that the Moringa peregrina tree shell ash is not only a low-cost adsorbent but also has a high performance in the removal of phenol from aqueous solutions (Zarei et al., 2013). In another research, the adsorption potential of pistachio-nut shell ash in a batch system was studied by Bazrafshan et al. (2012b) for the removal of phenol from aqueous solutions. The possibility of using rice husk and rice husk ash for removal of phenol from aqueous solution was investigated by Mahvi et al. (2004). Activated carbon prepared from rubber seed coat (RSCC), an agricultural waste by-product has been used for the adsorption of phenol from aqueous solution by Rengaraj et al. (2002b). Rao and Viraraghavan, (2002), have investigated the use of nonviable pretreated cells of Aspergillus niger to remove phenol from an aqueous solution. Five types of non-viable pretreated A. niger biomass powders were used as a biosorbent to remove phenol present in an aqueous solution at a concentration of $1000 \mathrm{~g} \mathrm{I}^{-1}$. Sulfuric acid pretreated A. niger biomass was found effective in the removal of phenol present in an aqueous solution at a concentration of $1000 \mathrm{~g} \mathrm{I}^{-1}$ (Rao and Viraraghavan, 2002). Findings of Tor et al. (2006) on the application of neutralized red mud for removal of phenol from aqueous solution showed that the neutralized red mud was an effective adsorbent for the removal of phenol from aqueous solutions. Higher phenol removal by neutralized red mud was possible provided that the initial phenol concentration was low in the solution 
(Tor et al., 2006). The potential of tendu (Diospyros melanoxylon) leaf refuse from local bidi industry, which itself is a solid waste disposal menace and its chemically carbonized product to adsorb phenol was investigated by Nagda et al. (2007). Activated carbon derived from avocado kernels (AAC) was evaluated for its ability to remove phenol by Rodrigues et al. (2011). Adsorption of phenol on natural clay for phenol removal from aqueous solutions have investigated by Djebbar et al. (2012). The phenol removal potential of clay, a low cost and abundantly available material has been investigated by Nayak and Singh (2007). Activated carbon derived from rattan sawdust (ACR) was evaluated by Hamid and Rahman (2008) for its ability to remove phenol from an aqueous solution in a batch process. Abdelwahab and Amin (2013) have analyzed the removal of phenol from aqueous solution by Adsorption on to Luffa cylindrical fibers (LC). Adsorption study for phenol removal from aqueous solution on activated palm seed coat carbon (PSCC) were carried out by Rengaraj et al. (2002a). A comparative study with a commercial activated carbon showed that PSCC is two times more effective than commercial activated carbon (CAC) (Rengaraj et al., 2002a). The vegetable sponge of cylindrical loofa, a natural product which rows in the north of Algeria, was used by Cherifi et al. (2009). Abdelkreem (2013) explored the possibility of using olive mill waste to remove phenol from aqueous effluents. The experimental studies on removal of phenol from waste water in a fluidized bed column using coconut shell activated carbon as an adsorbent have been reported by Kulkarni et al. (2013). Arris et al. (2012) showed that cereal by-product, an abundant natural material, can be used effectively and efficiently for the removal of phenol from wastewater. Rushdi et al. (2011) showed that Jordanian zeolite tuff can be used as a low cost adsorbent for the removal of phenol from water. Another investigation of the use of three carbonaceous materials, activated carbon (AC), bagasse ash (BA) and wood charcoal (WC), as adsorbents was studied by Mukherjee et al. (2007). Srivastava et al. (2006) research deals with the adsorption of phenol on carbon rich bagasse fly ash (BFA) and activated carboncommercial grade $(A C C)$ and laboratory grade $(A C L)$. The present study showed that the bagasse fly ash (BFA) is an effective adsorbent for the removal of phenol from aqueous solution (Srivastava et al., 2006). Karatay and Donmez (2014) have carried out the research on an economical phenol bio-removal method using Aspergillus versicolor and agricultural wastes as a carbon source. Viraraghavan and Alfaro (1998) examined the effectiveness of less expensive adsorbents such as peat, fly ash and bentonite in removing phenol from wastewater by adsorption. Batch adsorption research by Kilic et al. (2011) for the removal of phenol from aqueous solutions have been carried out by using activated carbon obtained from tobacco residue by chemical activation using $\mathrm{K}_{2} \mathrm{CO}_{3}$ and $\mathrm{KOH}$ as activation agents. A natural bentonite modified with a cationic surfactant, cetyl trimethyl ammonium bromide (CTAB), was used as an adsorbent for removal of phenol from aqueous solutions by Senturk et al. (2009). Application of a chemically modified green macro alga as a biosorbent for phenol removal have carried out by Aravindhan et al. (2009). The potential of bentonite for phenol adsorption from aqueous solutions was investigated by Banat et al. (2000). The removal of phenol (Ph) and 2-chlorophenol (2-CPh) from aqueous solution by native and heat inactivated fungus Funalia trogii pellets investigated by Bayramoglu et al. (2009). Batch adsorption experiments were conducted by Bahdod et al. (2009) to investigate the removal of phenol from wastewater by addition of three apatites (porous hydroxyapatite (PHAp) and crystalline hydroxyl- (HAp) and fluoroapatite (FAp). The adsorption of phenol from aqueous solutions was investigated using a carbonized beet pulp in the inert nitrogen atmosphere by Dursun et al. (2005). Results in comparative studies on adsorptive removal of phenol by three agro-based carbons, which have investigated by Srihari and Das (2008) showed that the black gram husk (BGH) is an effective adsorbent for the removal of phenol from aqueous solution when compared with green gram husk (GGH) and rice husk (RH). Activated carbons prepared from tamarind nutshell, an agricultural waste by-product, have been examined by Goud et al. (2005). Another Experiment have been conducted by Kermani et al. (2006) to examine the adsorption of phenol from aqueous solutions by rice husk ash and granular activated carbon (GAC). Phenol removal from aqueous system by jute stick has studied by Mustafa et al. (2008). In Siboni et al. (2013) research activated red mud containing iron and calcium as major components was applied to treat synthetic wastewater in a batch reactor. In another research the adsorption of phenol from wastewater was investigated using sawdust as adsorbent by Dakhil (2013). Moyo et al. (2012) investigated the possibility of Saccharomyces cerevisiae as an alternative adsorbent for phenol removal from aqueous solution. Adsorption of phenol from aqueous solution was investigated using sodium zeolite as an adsorbent by 
Saravanakumar and kumar (2013). The application of Colocasia esculenta as an alternative adsorbent for the removal of phenol from aqueous solution was investigated by Obi and Woke (2014). The potential of employing wheat husk for phenol adsorption from aqueous solution was studied by Jagwani and Joshi (2014). The potential of activated carbon prepared from Typha orientalis Presl to remove phenol from aqueous solutions was studied by Feng et al. (2015).

\section{Results and discussion}

\subsection{Effect of initial $\mathrm{pH}$ on adsorption effectiveness}

$\mathrm{pH}$ of the solution is one of the most critical parameters that affect the chemical properties of absorbing and adsorbing (Saitoh et al. 2011). The solution pH would affect both aqueous chemistry and surface binding sites of the adsorbent (Bazrafshan et al., 2013a). pH also affects the surface properties of the sorbent, i.e., surface charge of the cells used as sorbent (Aksu and Yener, 2001). Nagda et al. (2007) observed that the adsorption of phenol decreases by the increase of the $\mathrm{pH}$ value of the solution, which can be attributed to the phenol ionization to form phenolate ions and at the same time the presence of hydroxyl ions on the adsorbent prevents the uptake of phenolate ions (Halouli and Drawish, 1995). Similar trend has been reported during the adsorption of phenol onto bentonite (Banat et al., 2000). Hamid and Rahman (2008) defined the phenol removal by Activated carbon derived from rattan sawdust (ACR) was maximum and unaffected when the initial $\mathrm{pH}$ of the phenol solution was in the range of 3-8. A similar trend of $\mathrm{pH}$ effect was observed for the adsorption of phenol on activated carbon-commercial grade and laboratory grade (Srivastava et al., 2006). Generally, solution pH affects the surface charge of adsorbent and degree of ionization of the adsorbate (Aksu and Kabasakal, 2003). Similar result was given by Liu and Pinto (1997) for granule and spherical activated carbon. They reported that, the decrease in phenol adsorption from $\mathrm{pH}=6.3$ to 3.07 was due to the increased $\mathrm{H}^{+}$adsorption on the carbonyl sites, which suppresses phenol adsorption on these sites (Liu and Pinto, 1997). Similar trend has been reported during the adsorption of phenol onto activated carbon by Ekpete et al. (2010), onto rise husk by Mahvi et al. (2004) and onto agriculture waste by Tagreed (2010). Jagwani and Joshi (2014) concluded that adsorption amount decreased with increasing $\mathrm{pH}$ value, which can be attributed to the phenol ionization to form phenolate ions and at the same time the presence of hydroxyl ions on the adsorbent prevents the uptake of phenolate ions (Halouli and Drawish, 1995). Similar behavior has been reported during the adsorption of phenol onto tendu leaf refuse and modified carbon prepared from tendu leaf refuse by Nagda et al. (2007).

\subsection{Effect of adsorbent dose on the phenol removal by adsorption process}

Because adsorption is mainly a surface phenomenon, the amount of surface available for adsorption process and consequently the mass of adsorbent can considerably affect adsorption efficiency (Bazrafshan et al., 2014). In the investigation which was done by Rengaraj et al. (2002b) carbon dosage was varied from 0.5 to $10 \mathrm{~g}$ and equilibrated for $24 \mathrm{~h}$. It is evident that for the quantitative removal of 25 $\mathrm{mg} \mathrm{l}^{-1}$ of phenol in $100 \mathrm{ml}$, a minimum carbon dosage of $2.5 \mathrm{~g} \mathrm{RSCC}$ and $3.0 \mathrm{~g}$ of CAC is required for $96 \%$ removal of phenol. The data clearly showed that the RSCC is more effective than CAC for the removal of phenol. Abdelkreem (2013) indicated that phenol removal increased quickly from $52 \%$ to $85 \%$ when the olive mill waste dosage increased from $0.25 \mathrm{~g}$ to $1 \mathrm{~g}$ and reached a maximum for $1 \mathrm{~g}$ olive mill waste. This trend is expected because as the adsorbent dose increases, the number of active sites for binding phenol molecules on the adsorbent increases and thus more phenol was attached to their surface. Thus it results in the increment of adsorption efficiency until saturation. These results were agreed with those abstained by Ghaedi et al. (2011), and Smithaa et al. (2012). The minimum adsorbent dosage required was found by Srihari and Das (2008), they were $0.3,0.35$, and $0.4 \mathrm{~g}$ by BGH, GGH, and $\mathrm{RH}$, respectively. Thus, the adsorption trend of these agro based adsorbents was found to be in the following order: $B G H>G G H>R H$ (Srihari and Das, 2008). Findings of Siboni et al., (2013) work indicated that the increase in phenol removal with increase in the activated red mud amount is due to the increase of surface area and adsorption sites available for adsorption (Hameed and Rahman, 2008; Tor et al., 2009a; Lin and Juang, 2009; Shirzad-Siboni 
et al., 2011).Similar observations have also been reported from other research groups (Mohd Din et al., 2009; Banat et al., 2000; Tor et al., 2006; Lin and Juang, 2009; Tor et al., 2009b; Nayak and Singh, 2007).

\subsection{Effect of contact time on the phenol removal by adsorption process}

The contact time between adsorbate and adsorbent is one of the most important design parameters that affect the performance of adsorption processes (Bazrafshan et al., 2013b; Bazrafshan et al., 2015a). The removal efficiency increased with time and attained equilibrium in $3 \mathrm{~h}$ for PSCC and $6 \mathrm{~h}$ for CAC for initial phenol concentration of $25 \mathrm{mg} \mathrm{l}^{-1}$ In investigation on removal of phenol from aqueous solutions by activated red mud which has investigated by Siboni et al. (2013), while increasing the phenol concentration from 40 to $80 \mathrm{mg} \mathrm{l}^{-1}$, the removal percentage decreased from $90.3 \%$ to $76.6 \%$ at initial 30 min of contact time. After that, the removal percentage of phenol slowly increased and ranged from $90.4 \%$ to $80.6 \%$ at three different phenol concentrations after $60 \mathrm{~min}$. Further increase in the contact time has a negligible effect on the rate of phenol adsorption, and $60 \mathrm{~min}$ was determined as a near equilibration time (Siboni et al. 2013). The decrease in the removal percentage of phenol by increasing initial phenol concentration can be explained in that the adsorbent had a limited number of active sites, which can be easily saturated at higher adsorbate concentration (Hameed and Rahman, 2008; Al-Asheh et al., 2003; Tor et al., 2006; Tor et al., 2009). The results in Jagwani and Joshi (2014) research showed that equilibrium time required for the adsorption of phenol on wheat husk was almost $5 \mathrm{hr}$. The results also indicated that the sorption process can be considered very fast because of the largest amount of phenol attached to the sorbent within the first 120 min of adsorption as also observed by Mahvi et al. (2004), Mustafa et al. (2008) and Kermani et al. (2006). In addition similar findings were reported by other researchers about the increase of removal efficiency of pollutants with increase of contact time (Bazrafshan et al., 2015b; Bazrafshan et al., 2015c)

\subsection{Effect of initial phenol concentration on the effectiveness of adsorption process}

The initial concentration of pollutant provides an important driving force to overcome all mass transfer resistance of the adsorbate between the aqueous and solid phases (Anbia and Asl Hariri, 2010). Zarei et al. (2013) observed that phenol adsorption rate by Moringa peregrina tree shell ash will be increased by phenol concentration, so phenol elimination depends on its concentration. The results in Dakhil (2013) research indicated that the percentage of phenol removal increases with increasing the adsorbent dose. The high sorption at the initial concentration (100-500 mg l-1) may be due to an increased number of vacant sites on the adsorbent available at the initial stage. As concentration of initial phenol is increased there is a decrease in percentage removal of phenol. This can be attributed to the accumulation of phenol particles on the surface of adsorbent (Dakhil, 2013). This observation is in a good agreement with the findings of Ekpete et al. (2010) and Mahvi et al. (2004).

\subsection{Effect of temperature on phenol removal by adsorption process}

Temperature is an indicator for the adsorption nature whether it is an exothermic or endothermic process. Increasing temperature may decrease the adsorptive forces between the phenol species and the active sites on the adsorbent surface as a result of decreasing adsorption efficiency (Ofomaja and Ho, 2007; Jadhav and Vanjara, 2004). Senturk et al. (2009) concluded that the uptake of phenol by organo bentonite decreased from $6.2 \mathrm{mg} \mathrm{g}-1$ ( $59 \%$ removal) to $5.2 \mathrm{mg} \mathrm{g}-1$ (49.5\% removal) when increasing the temperature from 0 to $40^{\circ} \mathrm{C}$, which indicating that phenol uptake was favored at lower temperatures. The decrease in adsorption with the rise of temperature may be due to the weakening of adsorptive forces between the active sites of the adsorbent and adsorbate species and also between the vicinal molecules of the adsorbed phase (Panday et al., 1986; Mota and Lyubchik, 2008). Similar results were obtained by Hameed (2007) with adsorption of 2, 4, 6-trichlorophenol by activated clay.

\subsection{Adsorption isotherms}

Isotherms study can describe how an adsorbate interacts with the adsorbent. The isotherm provides a relationship between the concentration of phenol in solution and the amount of phenol adsorbed on the solid phase when both phases are in equilibrium (Anbia and Asl Hariri, 2010). The Langmuir, Freundlich, 
Temkin, BET, Redlich-Peterson and Dubinin-Radushkevich (D-R) isotherm models were used to describe the relationship between the amount of phenol adsorbed and its equilibrium concentration in solutions. Tor et al., (2006) reported the $\mathrm{R}^{2}$ values for linear form of Langmuir and Freundlich isotherms are 0.988 and 0.992 , respectively. According to $R^{2}$ values, the Freundlich isotherm best represents the equilibrium adsorption of phenol on neutralized red mud. This result is attributed that various active sites or heterogeneous mixture of several minerals on neutralized red mud has different affinities to phenol molecule (Genç-Fuhrman et al., 2004a; Genç-Fuhrman, 2004b). The well-known Freundlich, Langmuir isotherm equations were applied for the equilibrium adsorption data by Abdelkreem (2013) in the adsorption research of phenol from industrial wastewater using olive mill waste. The best-fitted adsorption isotherm models by Rushdi et al. (2011) were found to be in the order: Freundlich>Redlicheterson>Langmiur>Temkin for temperature range $25-45^{\circ} \mathrm{C}$.

\subsection{Thermodynamic parameters in the adsorption process}

Thermodynamic parameters are the actual indicators to determine where a process proceeds spontaneously and to ascertain if the process has any practical use (Nayak and Singh, 2007). The thermodynamic parameters that must be considered to determine the adsorption processes are the changes in standard enthalpy $\left(\Delta H^{0}\right)$, standard entropy $\left(\Delta S^{0}\right)$, and standard free energy $\left(\Delta \mathrm{G}^{0}\right)$ due to transfer of unit mole of solute from solution onto the solid-liquid interface (Rushdi et al., 2011). Adsorption process can be classified as physical adsorption and chemisorption by the magnitude of the enthalpy change. It is accepted that if magnitude of enthalpy change is lesser than $84 \mathrm{~kJ} \mathrm{~mol}^{-1}$, then the adsorption is physical. However chemisorption takes place in the range of $84-420 \mathrm{~kJ} \mathrm{~mol}^{-1}$ (Bazrafshan et al., 2015d; Bazrafshan et al., 2015e). Also If the process is endothermic $(\Delta \mathrm{H}>0)$, the equilibrium constant increases with temperature and If the process is exothermic $(\Delta \mathrm{H}<0)$, the equilibrium constant decreases as temperature is raised (Cherifi et al., 2009). The thermodynamic parameters are presented in Table 2.

Abdelwahab and Amin (2013) reported that the standard Gibbs free energies $\left(\Delta G^{0}\right)$ of adsorption were negative at all investigated temperatures. The negative values of $\Delta G^{0}$ of the adsorption confirmed that the adsorption of phenol onto LC was feasible and spontaneous (Fu et al., 2009; Su et al., 2011). Similar results were reported in the literature for the adsorption of phenol by organomontmorillonit (Fu et al., 2009) and adsorption of phenol onto chemically modified activated carbon (Canizares et al., 2006) and adsorption of phenol onto solid waste products from olive oil industry (Bhatnagar et al., 2014). Rushdi et al. (2011) reported that the Negative $\Delta G^{0}$ values are obtained at all temperatures revealing the spontaneous nature of these adsorptions. Generally, the values are close to each other indicating that such spontaneity is independent on the temperature where the adsorption occurs (Okolo et al., 2000). It is also supposed that the change of $\Delta S^{0}$ value is related to the displacement of the adsorbed water molecules by the adsorbate (Li et al., 2005). In this study, the negative $\Delta S^{0}$ value may reveal that zeolite surface does not prefer phenol molecules over adsorbed water molecules. Thus, the adsorption of phenol onto zeolite under employed conditions is considered as an enthalpy driven process (Bhatnagar and Sillanpaa, 2010).

\section{Conclusions}

Chemical contamination of water from a wide range of toxic pollutants, especially aromatic molecules, is a serious environmental problem due to potential human and environmental toxicity. Phenol and its derivatives appear to be the major organic pollutants globally in this century. They derived from many chemical plants and pesticide and dye manufacturing industries and cause serious threat to human health and to natural water. Adsorption is relatively new practice for the removal of phenol and its derivatives. In this article the role of activated carbon for the removal of phenol and its derivatives from water and wastewater was discussed. It is only able to remove few milligrams of phenol and its derivatives per gram of activated carbon and there are still some problems encountered in the regeneration process. This makes activated carbon an expensive adsorbent for this aim. Therefore, low-cost materials are needed 
that are comparable to activated carbon or synthetic resins in terms of adsorption capacity and should be locally available. The present review shows that several adsorbents (pistachio nut shell ash, Moringa peregrina tree shell ash, agricultural fibers, red mud, low cost clay and etc.) have equivalent or even more adsorption capacity to activated carbon and synthetic resins. It should be kept in mind that economic aspects are important. As an example, biosorption were found to be effective methods with scope for further research in this field in terms of cost effectiveness and regeneration. The alternative adsorbents mentioned in this article are found to be highly efficient for the removal of phenol and its derivatives. This is highly valuable for, not only the industries but the living organisms and the surrounding environment since they would be benefited from the potential toxicity. Thus the use of low-cost adsorbents may contribute to the sustainability of the surrounding environment. However, despite the number of published laboratory data, non-conventional low-cost adsorbents have not been applied at an industrial scale. Undoubtedly low-cost adsorbents offer a lot of promising benefits for commercial purpose in the future and the development of the adsorption process requires further investigation in the direction of testing low cost adsorbents with real industrial effluents. So there is a particular need for future studies to verify the performance of the promising low-cost adsorbents at the pilot plant scale.

\section{Competing interests}

The authors declare that they have no competing interests.

\section{Authors' contribution}

Edris Bazrafshan, Paria Amirian, Amir Hossein Mahvi and Alireza Ansari-Moghaddam contributed in writing of the manuscript and analyzing of data. All authors read and approved the final manuscript.

\section{Acknowledgment}

The authors thank the Zahedan University of Medical Sciences, Iran for all of the support provided.

\section{References}

Abdelkreem M. (2013), Adsorption of phenol from industrial wastewater using olive mill waste, APCBEE Procedia, 5 349-357.

Abdelwahab O. and Amin N.K. (2013), Adsorption of phenol from aqueous solutions by Luffa cylindrica fibers: kinetics, isotherm and thermodynamic studies, Egyptian Journal of Aquatic Research, 39, 215-223.

Ahmaruzzaman M.D. (2008), Adsorption of phenolic compounds on low-cost adsorbents: A review, Advances in Colloid and Interface Science, 143, 48-67.

Aksu Z. and Kabasakal E. (2003), Batch adsorption of 2, 4-dichlorophenoxy-acetic acid (2, 4-D) from aqueous solution by granular activated carbon, Separation and Purification Technology, 35, 223-240.

Al-Asheh S., Banat F. and Abu-Aitah L. (2003), Adsorption of phenol using different types of activated bentonites, Journal of Hazardous Materials, 33, 1-10.

Anbia M. and Asl Hariri S. (2010), Removal of methylene blue from aqueous solution using nanoporous SBA-3, Desalination, 261, 61-66.

Aravindhan R., Rao J.R. and Nair B.U. (2009), Application of a chemically modified green macro alga as a biosorbent for phenol removal, Journal of Environmental Management, 90, 1877-1883.

Arris S., Bencheikh Lehocine M. and Miniai H.A. (2012), Batch adsorption of phenol from industrial wastewater using cereal by-products as a new adsorbent, Energy procedia, 18, 1135-1144.

Bahdod A., El Asri S., Saoiabi A., Coradin T. and Laghzizil A. (2009), Adsorption of phenol from an aqueous solution by selected apatite adsorbents: kinetic process and impact of the surface properties, Water Research, 43, 313-318.

Bajaj M., Gallert C. and Winter J. (2008), Biodegradation of high phenol containing synthetic wastewater by an aerobic fixed bed reactor, Bioresource Technology, 99, 8376-8381.

Balasubramanian A. and Venkatesan S. (2012), Removal of phenolic compounds from aqueous solutions by emulsion liquid membrane containing Ionic Liquid (BMIM)+(PF6) - in Tributyl phosphate, Desalination, 289, 27-34. 
Banat F.A., Al-Bashir B., Al-Asheh S. and Hayajneh O. (2000), Adsorption of phenol by bentonite, Environmental Pollution, 107, 391-398.

Bayramoglu G., Gursel I., Tunali Y. and Arica M.Y. (2009), Biosorption of phenol and 2-chlorophenol by Funaliatrogii pellets, Bioresource Technology, 100, 2685-2691.

Bazrafshan E., Khoshnamvand N. and Mahvi A.H. (2015a), Fluoride removal from aqueous environments by $\mathrm{ZnCl}_{2}$ treated Eucalyptus leaf as a natural adsorbent, Fluoride, 48(4), 315-320.

Bazrafshan E., Kord Mostafapour F., Alizadeh M. and Farzadkia M. (2015b), Dairy wastewater treatment by chemical coagulation and adsorption on modified dried activated sludge: a pilot-plant study, Desalination and Water Treatment, 1-11 (in press).

Bazrafshan E., Alipour M.R. and Mahvi A.H. (2015c), Textile wastewater treatment by application of combined chemical coagulation, electrocoagulation, and adsorption processes, Desalination and Water Treatment, 1-13 (in press).

Bazrafshan E., Mostafapour F.K., Rahdar S. and Mahvi A.H. (2015d), Equilibrium and thermodynamics studies for decolorization of Reactive Black 5 (RB5) by adsorption onto MWCNTs, Desalination and Water Treatment, 54, 2241-225.

Bazrafshan E., Zarei A.A. and Kord Mostafapour F. (2015e), Biosorption of cadmium from aqueous solutions by Trichoderma fungus: kinetic, thermodynamic, and equilibrium study, Desalination and Water Treatment, 1-11 (in press).

Bazrafshan E., Zarei A.A., Nadi H. and Zazouli M.A. (2014), Adsorptive removal of Methyl Orange and Reactive Red 198 dyes by Moringa peregrine ash, Indian Journal of Chemical Technology, 21, 105-113.

Bazrafshan E., Ahmadabadi M. and Mahvi A.H. (2013a), Reactive Red-120 removal by activated carbon obtained from Cumin herb wastes, Fresenius Environmental Bulletin, 22(2a), 584-590.

Bazrafshan E., Mostafapour F.K., Hosseini A.R., Rakhsh Khorshid A. and Mahvi A.H. (2013b), Decolorisation of Reactive Red 120 Dye by using single-walled carbon nanotubes in aqueous solutions, Journal of Chemistry, 1-8.

Bazrafshan E., Kord Mostafapour F., Faridi H. and Zazouli M.A. (2012a), Application of Moringa peregrina seed extract as a natural coagulant for phenol removal from aqueous solutions, African Journal of Biotechnology, 11(103), 16758-16766.

Bazrafshan E., Biglari H. and Mahvi A.H. (2012b), Phenol removal by electrocoagulation process from aqueous solutions, Fresenius Environmental Bulletin, 21(2), 364-371.

Bazrafshan E., Kord Mostafapour F. and Mahvi A.H. (2012c), Phenol removal from aqueous solutions using pistachionut shell ash as a low cost adsorbent, Fresenius Environmental Bulletin, 21(10), 2962-2968.

Belhadj Tahara N. and Savall A. (2009), Electrochemical removal of phenol in alkaline solution, contribution of the anodic polymerization on different electrode materials, Electrochim Acta, 54, 4809-4816.

Bhatnagar A., Kaczala F., Hogland W., Marques M., Paraskeva C.A., Papadakis V.G. and Sillanpaa M. (2014), Valorization of solid waste products from olive oil industry as potential adsorbents for water pollution controla review, Environmental Science and Pollution Research, 21, 268-298.

Bhatnagar A. and Sillanpaa M. (2010), Utilization of agro-industrial and municipal waste materials as potential adsorbents for water treatment-a review, Chemical Engineering Journal, 157, 277-296.

Bodalo A., Gomez E., Hidalgo A.M., Gomez M., Murcia M.D. and Lopez I. (2009), Nanofiltration membranes to reduce phenol concentration in wastewater, Desalination, 245, 680-686.

Busca G., Berardinelli S., Resini C. and Arrighi L. (2008), Technologies for the removal of phenol from fluid streams: a short review of recent developments, Journal of Hazardous Materials, 160, 265-288.

Canizares P., Carmona M., Baraza O., Delgado A. and Rodrigo M.A. (2006), Adsorption equilibrium of phenol onto chemically modified activated carbon F400, Journal of Hazardous Materials, 131, 243-248.

Canizares P., Martinez F., Garcia-Gomez J., Saez C. and Rodrigo M.A. (2002), Combined electrooxidation and assisted electrochemical coagulation of aqueous phenol wastes, Journal of Applied Electrochemistry, 32, 1241-1246.

Cherifi H., Haninia S. and Bentaharb F. (2009), Adsorption of phenol from wastewater using vegetal cords as a new adsorbent, Desalination, 244, 177-187. 
Dakhil I.H. (2013), Removal of phenol from industrial wastewater using sawdust, International Journal of Engineering and Science, 3(1), 25-31.

Dianati-Tilaki R.A., Zazoli M.A., Yazdani J., Alamgholilu M. and Rostamali E. (2014), Degradation of 4-chlorophenol by sunlight using catalyst of zinc oxide, Journal of Mazandaran University of Medical Sciences, 23(Suppl 2), 196-201 (in Persian).

Djebbar M., Djafri F., Bouchekara M. and Djafri A. (2012), Adsorption of phenol on natural clay, Applied Water Science, 2, 77-86.

Donmez G.C., Aksu Z., Öztürk A. and Kutsal T. (1999), A comparative study on heavy metal biosorption characteristic of some algae, Process Biochemistry, 34(5), 885-892.

Dursun G., Cicek H., Dursun A.Y. (2005), Adsorption of phenol from aqueous solution by using carbonized beet pulp, Journal of Hazardous Materials, B125, 175-182.

Ekpete O.A., Horsfall M. and Tarawou T. (2010), Potential of fluid and commercial activated carbons for phenol removal in aqueous systems, ARPN Journal of Engineering and Applied Sciences, 5(9), 39-47.

El-Naas M.H., Al-Zuhair S. and Abu Alhaija M. (2010), Removal of phenol from petroleum refinery wastewater through adsorption on date-pit activated carbon, Chemical Engineering Journal, 162, 997-1005.

Feng J., Qiao K., Pei L., Lv J. and Xie S. (2015), Using activated carbon prepared from Typha Orientalis Pres/ to remove phenol from aqueous solutions, Ecological Engineering, 84, 209-217.

Fu Q.L., Deng Y.L., Li H.S., Liu J., Hua H.Q., Chen S.W. and Sa T.M. (2009), Equilibrium, kinetic and thermodynamic studies on the adsorption of the toxins of Bacillus thuringiensis subsp. kurstaki by clay minerals, Applied Surface Science, 255, 4551-4557.

Genç-Fuhrman H., Tjell J.C. and McConchie D. (2004a), Adsorption of arsenic from water using activated neutralised red mud, Environmental Science and Technology, 38, 2428-2434.

Genc-Fuhrman H. Ph.D. thesis, Environment and Resources. DTU Technical University of Denmark, Denmark. 2004b.

Ghaedi M., Ramazani S. and Roosta M. (2011), Gold nanoparticle loaded activated carbon as novel adsorbent for the removal of Congo red, Indian Journal of Science and Technology, 4(10), 1208-1217.

Goud V.V., Mohanty K., Rao M.S. and Jayakumar N.S. (2005), Phenol removal from aqueous solutions by Tamarind Nut shell activated carbon: batch and column studies, Chemical Engineering and Technology, 28(7), 814-821.

Gurses A. and Yalcin M. (2005), Removal of phenolic and lignin compounds from bleached kraft mill effluent by fly ash and sepiolite, Adsorption, 11, 87-97.

Halouli K.A. and Drawish N.M. (1995), Effects of pH and inorganic salts on the adsorption of phenol from aqueous systems on activated decolourising charcoal, Separation Science and Technology, 30, 3313-3324.

Hameed B.H. and Rahman A.A. (2008), Removal of phenol from aqueous solutions by adsorption on to Activated carbon prepared from biomass material, Journal of Hazardous Materials, 160, 576-581.

Hameed B.H. (2007), Equilibrium and kinetics studies of 2, 4, 6-trichlorophenol adsorption onto activated clay, Colloid Surface A: Physicochemical and Engineering Aspects, 307, 45-52.

Jadhav D.N. and Vanjara A.K. (2004), Removal of phenol from wastewater using sawdust, polymerized sawdust and sawdust carbon, Indian Journal of Chemical Technology, 2, 35-41.

Jagwani D. and Joshi P. (2014), Deportation of toxic phenol from aqueous system by wheat husk, International Journal of Plant, Animal and Environmental Sciences, 4(2), 58-64.

Juang R.S.H., Kao H.C.H. and Tseng K.J. (2010), Kinetics of phenol removal from saline solutions by solvent extraction coupled with degradation in a two-phase partitioning bioreactor, Separation and Purification Technology, 71(3), 285-292.

Jung M.W., Ahn K.H., Lee Y., Kim K.P., Rhee J.S. and Tae Park J. (2001), Adsorption characteristics of phenol and chlorophenols on granular activated carbons (GAC), Microchemical Journal, 70, 123-131.

Kapoor A., Viraraghavan T. and Cullimore D.R. (1999), Removal of heavy metals using the fungus Aspergillus niger, Bioresource Technology, 70(1), 95-104.

Karatay S.E. and Donmez G. (2014), An economical phenol bioremoval method using Aspergillus versicolor and agricultural wastes as a carbon source, Ecological Engineering, 73, 224-328.

Kermani M., Pourmoghaddas H., Bina B. and Khazaei Z. (2006), Removal of phenol from aqueous solutions by rice 
husk ash and activated carbon, Pakistan Journal of Biological Sciences, 9(10), 1905-1910.

Kilic M., Apaydin-Varol E. and Pütün A.E. (2011), Adsorptive removal of phenol from aqueous solutions on activated carbon prepared from tobacco residues: equilibrium, kinetics and thermodynamics, Journal of Hazardous Materials, 189, 397-403.

Kulkarni S. and Kaware J. (2013), Adsorption for phenol removal-A Review, International Journal of Scientific Engineering and Research, 1(2), 88-96.

Kulkarni SJ, Tapreb RW, Patilc SV, Sawarkard MB. Adsorption of Phenol from Wastewater in Fluidized Bed Using Coconut Shell Activated Carbon. Procedia Engineering. 2013; 51: 300-307.

Li H.Q., Han H.J., Du M.A. and Wang W. (2011), Removal of phenols, thiocyanate and ammonium from coal gasification wastewater using moving bed biofilm reactor, Bioresource Technology, 102, 4667-4673.

Li Y.H., Di Z., Ding J., Wu D., Luan Z. and Zhu Y. (2005), Adsorption thermodynamic, kinetic and desorption studies of $\mathrm{Pb}^{2+}$ on carbon nanotubes, Water Research, 39, 605-609.

Lin S.H. and Juang R.S. (2009), Adsorption of phenol and its derivatives from water using synthetic resins and lowcost natural ad sorbents: a review, Journal of Environmental Management, 90, 1336-1349.

Liu X. and Pinto N.G. (1997), Ideal adsorbed phase model for adsorption of phenolic compounds on activated carbon, Carbon, 35, 1387-1397.

Mahvi A.H. (2009), Application of ultrasonic technology for water and wastewater treatment, Iranian Journal of Public Health., 38(2), 1-17.

Mahvi A.H. (2008), Application of agricultural fibers in pollution removal from aqueous solution, International Journal of Environmental Science and Technology, 5(2), 275-285.

Mahvi A.H., Maleki A., Alimohamadi M. and Ghasri A. (2007), Photo-oxidation of phenol in aqueous solution: Toxicity of intermediates, Korean Journal of Chemical Engineering, 24(1), 79-82.

Mahvi A.H., Maleki A. and Eslami A. (2004), Potential of rice husk and rice husk ash for phenol removal in aqueous system, American Journal of Applied Sciences, 1(4), 321-326.

Maleki A., Mahvi A.H., Mesdaghinia A. and Naddafi K. (2007), Degradation and toxicity reduction of phenol by ultrasound waves, Bulletin of the chemical society of Ethiopia, 21(1), 33-38.

Mao X., Buchanan I.D. and Stanley S.J. (2006), Phenol removal from aqueous solution by fungal peroxidases, Journal of Environmental Engineering and Science, 5(1), 103-109.

Mohan D. and Chander O.S. (2001), Single component and multi-component adsorption of phenols by activated carbons, Colloid Surface A. Physicochemical and Engineering Aspects, 177, 183-196.

Mohd Din A.T., Hameed B.H. and Ahmad A.L. (2009), Batch adsorption of phenol onto physiochemical-activated coconut shell, Journal of Hazardous Materials, 161, 1522-29.

Mota J.P. and Lyubchik S. Recent advances in adsorption processes for environmental protection and security. Springer, New York. 2008.

Moussavi G.H., Barikbin B. and Mahmoudi M. (2010), The removal of high concentrations of phenol from saline wastewater using aerobic granular SBR, Chemical Engineering Journal, 158, 498-504.

Moyo M., Mutare E., Chigondo F. and Nyamunda B.C. (2012), Removal of phenol from aqueous solution by adsorption on yeast, saccharomyces cerevisiae, International Journal of Research and Reviews in Applied Science, 11(3), 486-494.

Mukherjee S., Kumarb S., Misra A.K. and Fan M. (2007), Removal of phenols from water environment by activated carbon, bagasse ash and wood charcoal, Chemical Engineering Journal, 129, 133-142.

Muraleedharan T.R., lyenger L. and Venkobachar C. (1991), Biosorption - an attractive alternative for metal removal and recovery, Current Science, 61, 379-384.

Mustafa A.I., Saiful Alam Md, Nurul Amin Md, Bahadur N.M. and AhsanHabib M.D. (2008), Phenol removal from aqueous system by Jute Stick, Pakistan Journal of Analytical and Environmental Chemistry, 9(2), 92-95.

Nagda G.K., Diwan A.M. and Ghole V.S. (2007), Potential of Tendu leaf refuse for phenol removal in aqueous systems, Applied Ecology and Environmental Research, 5(2), 1-9. 
Nayak P.S. and Singh B.K. (2007), Removal of phenol from aqueous solutions by sorption on low cost clay, Desalination, 207, 71-79.

Nazari K., Esmaeili N., Mahmoudi A., Rahimi H. and Moosavi-Movahedi A. (2007), Peroxidative phenol removal from aqueous solutions using activated peroxidase biocatalyst, Enzyme and Microbial Technology, 41, 226-233.

Obi C. and Woke J. (2014), The removal of phenol from aqueous solution by Colocasia esculenta araesia Linn Schott, Sky Journal of Soil Science and Environmental Management, 3(6), 59-66.

Ofomaja A.E. and Ho Y.S. (2007), Equilibrium sorption of anionic dye from aqueous solution by palm kernel fibre as sorbent, Dyes Pigments, 74, 60-66.

Okolo B., Park C. and Keane M.A. (2000), Interaction of phenol and chlorophenols with activated carbon and synthetic zeolites in aqueous media, Journal of Colloid and Interface Science, 226, 308-317.

Panday K.K., Prasad G. and Singh V.N. (1986), Use of wallastonite for the treatment of Cu (II) rich effluents, Water, Air and Soil Pollution, 27, 287-296.

Pandit A.B., Gogate P.R. and Mujumdar S. (2001), Ultrasonic degradation of 2, 4, 6 trichlorophenol in presence of $\mathrm{TiO}_{2}$ catalyst, Ultrasonic Sonochemistry, 8, 227-231.

Perez-Rama M., Alonso J.A., Lopez C.H. and Vaamonde E.T. (2002), Cadmium removal by living cells of the marine microalga tetra selmissuecica, Bioresource Technology, 84(3), 265-270.

Radeke K.H., Loseh D., Struve K. and Weiss E. (1993), Comparing adsorption of phenolfrom aqueous solution onto silica fangasite, activated carbon and polymeric resin, Zeolites, 13, 69-70.

Radovic L.R., Moreno-Castilla C. and Rivera-Utrilla J. (2001), Carbon materials as adsorbents in aqueous solutions. In: Radovic, L.R. (Ed.). Chemistry and Physics of Carbon, A Series of Advances, 27: 227-405.

Rao J.R. and Viraraghavan T. (2002), Biosorption of phenol from an aqueous solution by Aspergillus niger biomass, Bioresource Technology, 85, 65-71.

Rengaraj S., Moon S., Sivabalan R., Arabindoo B. and Murugesan V.J. (2002b), Removal of phenol from aqueous solution and resin manufacturing industry wastewater using an agricultural waste: rubber seed coat, Journal of Hazardous Materials, 89, 185-196.

Rengaraj S., Moon S.H., Sivabalan R., Arabindoo B. and Murugesan V. (2002a), Agricultural solid waste for the removal of organics: adsorption of phenol from water and wastewater by palm seed coat activated carbon, Waste Management, 22(5), 543-548.

Rodrigues L.A., da Silva M.L.C.P., Alvarez-Mendes M.O., Coutinho A.D.R. and Thim G.P. (2011), Phenol removal from aqueous solution by activated carbon produced from avocado kernel seeds, Chemical Engineering Journal, 174, 49-57.

Rushdi I.Y., Bassam E.E. and Ala'aH A.M. (2011), Adsorption characteristics of natural zeolites as solid adsorbents for phenol removal from aqueous solutions: kinetics, mechanism, and thermodynamics studies, Chemical Engineering Journal, 171, 1143-1149.

Saitoh T., Asano K. and Hiraide M. (2011), Removal of phenols in water using chitosan-conjugated thermoresponsive polymers, Journal of Hazardous Materials, 185, 1369-1373.

Saravanakumar K. and Kumar A. (2013), Removal of phenol from aqueous solution by adsorption using zeolite, African Journal of Agricultural Research, 8(23), 2965-2969.

Satendra K., Upadhyay S.N. and Upadhyay Y.D. (1987), Removal of phenols by adsorption on fly ash, Journal of Chemical Technology and Biotechnology, 37, 281-290.

Senturk H.B., Ozdes D., Gundogdu A., Duran C. and Soylak M. (2009), Removal of phenol from aqueous solutions by adsorption onto organomodified Tirebolubentonite: Equilibrium, kinetic and thermodynamic study, Journal of Hazardous Materials, 172, 353-362.

Shirzad-Siboni M., Samarghandi M.R., Azizian S., Kim W.G. and Lee S.M. (2011), The removal of hexavalent chromium from aqueous solutions using modifed holly sawdust: equilibrium and kinetics studies, Environmental Engineering Research, 16, 55-60.

Siboni M.S., Jafari S.J., Farrokhi M. and Yang J.K. (2013), Removal of phenol from aqueous solutions by activated Red Mud: Equilibrium and kinetics studies, Environmental Engineering Research, 18(4), 247-252.

Singh D.K. and Srivastava B. (2002), Removal of phenol pollutants from aqueous solution using various adsorbents, Journal of Scientific and Industrial Research, 61, 208-218. 
Smithaa T., Thirumalisamy S. and Manonani S. (2012), Equilibrium and kinetics study of adsorption of crystal violet onto the peel of Cucumis sativa fruit from aqueous solution, E-Journal of Chemistry, 9(3), 1091-101.

Srihari V. and Das A. (2008), Comparative studies on adsorptive removal of phenol by three agro-based carbons: equilibrium and isotherm studies, Ecotoxicology and Environmental Safety, 71, 274-283.

Srivastava V.C., Swamy M.M., Mall I.M., Prasad B. and Mishra I.M. (2006), Adsorptive removal of phenol by bagasse fly ash and activated carbon: equilibrium, kinetics and thermodynamics, Colloids and Surfaces A: Physicochemical and Engineering Aspects, 272, 89-104.

Sternberg S.P.K. and Dorn R.W. (2002), Cadmium removal using cladophora in batch, semi batch and flow reactors, Bioresource Technology, 81(3), 249-255.

Su J., Lin Hong-fu, Wang Qing-Ping, Xie Zheng-Miao, Chen Zu-liang (2011), Adsorption of phenol from aqueous solutions by organomontmorillonite, Desalination, 269, 163-169.

Tagreed L.A. (2010), Removal of phenol from aqueous solution by agriculture waste, Engineering and Technology Journal, 28(19).

Tor A., Cengeloglu Y., Aydin A. and Ersoz M. (2006), Removal of phenol from aqueous phase by using neutralized red mud, Journal of Colloid and Interface Science, 300, 498-503.

Tor A., Danaoglu N., Arslan G. and Cengeloglu Y. (2009a), Removal of fuoride from water by using granular red mud: batch and column studies, Journal of Hazardous Materials, 164, 271-278.

Tor A., Cengeloglu Y. and Ersoz M. (2009b), Increasing the phenol adsorption capacity of neutralized red mud by application of acid activation procedure, Desalination, 242, 19-28.

Viraraghavan T. and De Maria Alfaro F. (2000), Adsorption of phenol from wastewater by peat, fly ash and bentonite, Journal of Hazardous Materials, 57(1-3), 59-70.

Yavuz Y. and Koparal A.S. (2006), Electrochemical oxidation of phenol in a parallel plate reactor using ruthenium mixed metal oxide electrode, Journal of Hazardous Materials, 136, 296-302.

Zarei A., Bazrafshan E., Faridi H., Khaksefidi R. and Alizadeh M. (2013), The evaluation of removal efficiency of phenol from aqueous solutions using Moringa peregrina tree shell ash, Iranian Journal of Health Sciences, 1(1), 65-74. 
Table 1. Application of adsorption process by using various adsorbents for phenol and phenolic compounds removal from aqueous environments

\begin{tabular}{|c|c|c|c|c|c|c|c|c|c|c|c|c|c|}
\hline \multirow[b]{2}{*}{ Adsorbent } & \multirow[b]{2}{*}{$\mathrm{C}_{0}\left(\mathrm{mg} \mathrm{l}^{-1}\right)$} & \multirow[b]{2}{*}{ pH } & \multirow{2}{*}{$\begin{array}{l}\text { Contact } \\
\text { time } \\
\text { (min) }\end{array}$} & \multirow{2}{*}{$\begin{array}{l}\text { Adsorbent } \\
\text { dose }\left(\mathrm{g}^{-1}\right)\end{array}$} & \multirow[b]{2}{*}{$\begin{array}{l}\text { Optimu } \\
\mathrm{mpH}\end{array}$} & \multirow[b]{2}{*}{$\begin{array}{l}\text { Optimum } \\
\text { dose }\left(\mathrm{g}^{\left.\left.\right|^{-1}\right)}\right.\end{array}$} & \multirow[b]{2}{*}{$\begin{array}{c}\text { Temperature } \\
\left({ }^{\circ} \mathrm{C}\right)\end{array}$} & \multirow[b]{2}{*}{$\begin{array}{l}\text { Equilibrium } \\
\text { time (min) }\end{array}$} & \multirow[b]{2}{*}{$\begin{array}{c}\text { Removal } \\
\text { efficiency (\%) }\end{array}$} & \multirow{2}{*}{$\begin{array}{l}\text { Adsorption } \\
\text { capacity (qe) } \\
\left(\mathrm{mg} \mathrm{g}^{-1}\right)\end{array}$} & \multicolumn{2}{|c|}{ Isotherms } & \multirow[b]{2}{*}{ References } \\
\hline & & & & & & & & & & & Freundlich & Langmuir & \\
\hline $\begin{array}{c}\text { Moringa } \\
\text { peregrina tree } \\
\text { shell ash }\end{array}$ & $10-100$ & $2-12$ & $15-210$ & $0.1-0.7$ & 6 & 0.4 & $23 \pm 2$ & 45 & 97.82 & 164.23 & $R^{2}=0.94$ & $R^{2}=0.96$ & (Zarei et al., 2013) \\
\hline $\begin{array}{l}\text { Pistachio nut } \\
\text { shell ash }\end{array}$ & $1-100$ & $2-13$ & $15-120$ & $0.1-0.6$ & 5 & 0.3 & $25 \pm 2$ & 45 & 98.28 & 327.6 & $R^{2}=0.94$ & $R^{2}=0.83$ & $\begin{array}{c}\text { (Bazrafshan et al., } \\
\text { 2012c) }\end{array}$ \\
\hline Rice husk & $0.15-0.5$ & 5-11 & $10-180$ & 1- 7 & 5 & 0.3 & $23 \pm 2$ & 360 & 27 & - & $R^{2}=0.96$ & $\mathrm{R}^{2}=0.87$ & \multirow{2}{*}{ (Mahvi et al., 2004a) } \\
\hline Rice husk ash & $0.5-1.3$ & 5-11 & $10-180$ & $0.1-0.5$ & 7 & 0.3 & $23 \pm 2$ & 180 & 96 & 0.886 & $\mathrm{R}^{2}=0.98$ & $\mathrm{R}^{2}=0.97$ & \\
\hline $\begin{array}{l}\text { Rubber seed coat } \\
\text { (RSCC) }\end{array}$ & $10-30$ & $1-14$ & $15-1440$ & $0.5-10$ & 6.2 & 2.5 & $27 \pm 1$ & 180 & 96 & - & $\mathrm{R}^{2}=0.3$ & - & \multirow{2}{*}{$\begin{array}{l}\text { (Rengaraj et al., } \\
\text { 2002b) }\end{array}$} \\
\hline $\begin{array}{l}\text { CAC (commercial } \\
\text { activated carbon) }\end{array}$ & $10-30$ & $1-14$ & $15-1440$ & $0.5-10$ & 6.2 & 3.0 & $27 \pm 1$ & 360 & 96 & - & $R^{2}=0.9$ & - & \\
\hline Aspergillus niger & 1.0 & $2-10$ & 1800 & $0.05-0.45$ & 5.1 & 0.2 & $21 \pm 1$ & 1440 & 66 & - & $\mathrm{R}^{2}=0.73$ & $\mathrm{R}^{2}=0.72$ & $\begin{array}{c}\text { (Rao and } \\
\text { Viraraghavan, 2002) } \\
\end{array}$ \\
\hline $\begin{array}{l}\text { Neutralized red } \\
\text { mud }\end{array}$ & $5-200$ & $1-12$ & $10-840$ & $1-10$ & 6 & 10 & $25 \pm 1$ & 600 & 48 & 42 & $R^{2}=0.99$ & $R^{2}=0.98$ & (Tor et al., 2006) \\
\hline $\begin{array}{l}\text { Tendu leaf refuse } \\
\text { (TLR) }\end{array}$ & $10-200$ & $4.2-12$ & $60-480$ & $\begin{array}{l}0.1-100 \\
\mathrm{mg} \mathrm{m}^{-1}\end{array}$ & 8.5 & $3 \mathrm{mg} \mathrm{ml}^{-1}$ & $25 \pm 1$ & 120 & 48 & 1.9 & $R^{2}=0.97$ & $\mathrm{R}^{2}=0.95$ & \multirow{2}{*}{ (Nagda et al., 2007) } \\
\hline $\begin{array}{l}\text { Tendu leaf refuse } \\
\text { (TLR-CM) }\end{array}$ & $10-200$ & $4.2-12$ & $10-240$ & $\begin{array}{c}0.1-50 \\
\mathrm{mg} \mathrm{ml}^{-1}\end{array}$ & 8.5 & $0.5 \mathrm{mg} \mathrm{m}^{-1}$ & $25 \pm 1$ & 60 & 98 & 39 & $R^{2}=0.98$ & $R^{2}=0.96$ & \\
\hline $\begin{array}{l}\text { Activated carbon } \\
\text { derived from } \\
\text { avocado kernels } \\
\text { (AAC) }\end{array}$ & $\begin{array}{c}100-600 \mathrm{mg} \\
\mathrm{dm}^{-3}\end{array}$ & $2-8$ & $0-250$ & $0.02-0.20$ & $4-8.5$ & 0.1 & 25 & 15 & 69 & 117 & $R^{2}=0.94$ & $R^{2}=0.99$ & $\begin{array}{c}\text { (Rodrigues et al., } \\
\text { 2011) }\end{array}$ \\
\hline Natural clay & $\begin{array}{c}100 \mathrm{ml}^{\text {of }} 5 \\
\mathrm{mg} \mathrm{l}^{-1}\end{array}$ & $4-8$ & $0-3000$ & $1-5 \mathrm{mg}$ & 5 & $5 \mathrm{mg}$ & 23 & 300 & 60 & - & $R^{2}=0.94$ & $\mathrm{R}^{2}=0.92$ & \multirow[t]{2}{*}{ (Djebbar et al., 2012) } \\
\hline Activated clay & 5 & $4-8$ & & $1-5 \mathrm{mg}$ & 5 & $5 \mathrm{mg}$ & 23 & 300 & 70 & 15 & $R^{2}=0.97$ & $\mathrm{R}^{2}=0.98$ & \\
\hline Low cost clay & $\begin{array}{c}500 \\
\mathrm{mg} \mathrm{dm}^{-3}\end{array}$ & $2-10$ & - & - & 6.5 & - & 30 & - & 37.56 & - & - & - & $\begin{array}{c}\text { (Nayak and Singh, } \\
\text { 2007) }\end{array}$ \\
\hline (ACR) & $25-200$ & 3-10 & 1440 & 0.20 & 4 & 0.20 & 30 & 240 & & 149.25 & $R^{2}=0.86$ & $R^{2}=0.98$ & $\begin{array}{c}\text { (Hamid and Rahman, } \\
\text { 2008) }\end{array}$ \\
\hline $\begin{array}{l}\text { Luffa cylindrica } \\
\text { fibers (LC) }\end{array}$ & $5-40$ & $2-12$ & $0-150$ & $1-5$ & 7 & 3 & 20 & 120 & 85 & 10.37 & $R^{2}=0.94$ & $R^{2}=0.99$ & $\begin{array}{l}\text { (Abdelwahab and } \\
\text { Amin, 2013) }\end{array}$ \\
\hline
\end{tabular}




\begin{tabular}{|c|c|c|c|c|c|c|c|c|c|c|c|c|c|}
\hline (PSCC) & $10-60$ & $1-13$ & 1440 & $0.5-10$ & $4-9$ & 2 & $27 \pm 1$ & 120 & 96 & - & - & - & (Rengaraj et al., \\
\hline (CAC) & $10-60$ & $1-13$ & 1440 & $0.5-10$ & $4-9$ & 3 & $27 \pm 1$ & 360 & 96 & - & - & - & 2002a) \\
\hline cylindrical loofa & $0-50$ & 8.5 & 120 & 0.1 & 8.5 & 0.1 & 23 & 50 & - & 4.70 & $R^{2}=0.86$ & $\mathrm{R}^{2}=0.94$ & (Cherifi et al., 2009) \\
\hline Olive Mill Waste & $100-600$ & - & 120 & $0.25-1$ & - & 1 & 20 & 120 & 85 & - & $R^{2}=0.90$ & $R^{2}=0.96$ & (Abdelkreem, 2013) \\
\hline $\begin{array}{c}\text { Coconut Shell } \\
\text { Activated Carbon }\end{array}$ & $100-300$ & - & $10-60$ & 5 & - & 5 & $25 \pm 1$ & $15-20$ & 46 & - & $\mathrm{R}^{2}=0.98$ & - & (Kulkarni et al., 2013) \\
\hline $\begin{array}{c}\text { Cereal by- } \\
\text { products }\end{array}$ & 20 & $2-10$ & $0-350$ & 10 & 3 & 10 & 20 & 120 & 70 & - & $\mathrm{R}^{2}=0.72$ & $R^{2}=0.58$ & (Arris et al., 2012) \\
\hline $\begin{array}{c}\text { Natural zeolites } \\
\text { (Jordanian } \\
\text { zeolitic tuff) }\end{array}$ & $10-90$ & 4 & $0-1440$ & - & 4 & - & 25 & 120 & 96 & 32.6 & $\mathrm{R}^{2}=0.99$ & $\mathrm{R}^{2}=0.97$ & (Rushdi et al., 2011) \\
\hline $\begin{array}{l}\text { Activated carbon } \\
\text { (AC) }\end{array}$ & $20-100$ & $2-10$ & $0-6 \mathrm{~h}$ & $\begin{array}{c}30 \text { and } 50 \\
\mathrm{mg} \mathrm{l}^{-1}\end{array}$ & 6.8 & 10 & $24 \pm 1$ & 60 & 98 & $\begin{array}{c}0.98 \\
\mathrm{mg} \mathrm{mg}^{-1}\end{array}$ & $\mathrm{R}^{2}=0.90$ & - & \multirow{3}{*}{$\begin{array}{l}\text { (Mukherjee et al., } \\
\text { 2007) }\end{array}$} \\
\hline Bagasse ash (BA) & $20-100$ & $2-10$ & $0-360$ & $\begin{array}{c}30 \text { and } 50 \\
\mathrm{mg} \mathrm{l}^{-1}\end{array}$ & 6.8 & 15 & $24 \pm 1$ & 60 & 90 & $\begin{array}{c}0.88 \\
\mathrm{mg} \mathrm{mg}^{-1}\end{array}$ & $\mathrm{R}^{2}=0.92$ & - & \\
\hline $\begin{array}{l}\text { Wood charcoal } \\
\text { (WC) }\end{array}$ & $20-100$ & $2-10$ & $0-360$ & $\begin{array}{c}30 \text { and } 50 \\
\mathrm{mg} \mathrm{l}^{-1}\end{array}$ & 6.8 & 60 & $24 \pm 1$ & 60 & 90 & $\begin{array}{c}0.89 \\
\mathrm{mg} \mathrm{mg}^{-1}\end{array}$ & $\mathrm{R}^{2}=0.90$ & - & \\
\hline $\begin{array}{c}\text { 46346Carbon rich } \\
\text { bagasse fly ash } \\
\text { (BFA) }\end{array}$ & $75-300$ & $3-10$ & $0-1440$ & $1-10$ & 6.5 & 10 & 30 & 300 & - & - & $\mathrm{R}^{2}=0.99$ & $\mathrm{R}^{2}=0.98$ & \multirow{3}{*}{$\begin{array}{l}\text { (Srivastava et al., } \\
\text { 2006) }\end{array}$} \\
\hline $\begin{array}{l}\text { Activated carbon- } \\
\text { commercial grade } \\
\text { (ACC) }\end{array}$ & $75-300$ & $3-10$ & $0-1440$ & $1-10$ & 6.5 & 12 & 30 & 300 & - & - & $\mathrm{R}^{2}=0.97$ & $\mathrm{R}^{2}=0.99$ & \\
\hline $\begin{array}{l}\text { Laboratory grade } \\
\qquad(A C L)\end{array}$ & $75-300$ & $3-10$ & $0-1440$ & $1-10$ & 6.5 & 10 & 30 & 300 & - & - & $\mathrm{R}^{2}=0.99$ & $\mathrm{R}^{2}=0.95$ & \\
\hline MSG & $100-600$ & $4-7$ & 4320 & 1 & 6 & 1 & 30 & 60 & 61.5 & 149.64 & - & - & \multirow{3}{*}{$\begin{array}{l}\text { (Karatay and } \\
\text { Dönmez, 2014) }\end{array}$} \\
\hline MSA & $100-600$ & 4-7 & 4320 & 1 & 6 & 1 & 30 & 60 & 98.7 & 261.88 & - & - & \\
\hline MSC & $100-600$ & $4-7$ & 4320 & 1 and 5 & 6 & 1 & 30 & 60 & 100 & 274.29 & - & & \\
\hline Peat & 1 & $2-8$ & 1440 & - & $4-5$ & - & $21 \pm 1$ & 960 & 46.1 & - & $R^{2}=0.86$ & - & \multirow{3}{*}{$\begin{array}{c}\text { (Viraraghavan and } \\
\text { Alfaro, 1998) }\end{array}$} \\
\hline Fly ash & 1 & $2-8$ & 1440 & - & $4-5$ & - & $21 \pm 1$ & 300 & 41.6 & - & - & $\mathrm{R}^{2}=0.97$ & \\
\hline Bentonite & 1 & $2-8$ & 1440 & - & $4-5$ & - & $21 \pm 1$ & 960 & 42.5 & - & $\mathrm{R}^{2}=0.86$ & & \\
\hline $\begin{array}{l}\text { Tobacco residues } \\
\text { (ACK1) }\end{array}$ & $1-12$ & $5-9$ & $10-240$ & $0.5-8$ & 7 & 2 & 20 & 120 & 90.5 & - & $R^{2}=0.99$ & $R^{2}=0.99$ & \multirow{2}{*}{ (Kilic et al., 2011) } \\
\hline $\begin{array}{l}\text { Tobacco residues } \\
\text { (ACK2) }\end{array}$ & $1-12$ & $5-9$ & $10-240$ & $0.5-8$ & 8 & 4 & 20 & 120 & 87.6 & - & $R^{2}=0.99$ & $R^{2}=0.92$ & \\
\hline
\end{tabular}




\begin{tabular}{|c|c|c|c|c|c|c|c|c|c|c|c|c|c|}
\hline $\begin{array}{c}\text { Organomodified } \\
\text { Tirebolu } \\
\text { bentonite }\end{array}$ & $100-1000$ & $1-11$ & $0-500$ & $1-25$ & 9 & 10 & 20 & 60 & 58.5 & - & $R^{2}=0.99$ & $R^{2}=0.99$ & (Senturk et al., 2009) \\
\hline $\begin{array}{l}\text { Caulerpascal- } \\
\text { Pelliformi }\end{array}$ & 10-150 & $2-10$ & 360 & 6 & 6 & 6 & $30 \pm 1$ & 240 & 93.58 & 20 & $R^{2}=0.97$ & $R^{2}=0.98$ & $\begin{array}{c}\text { (Aravindhan et al., } \\
\text { 2009) }\end{array}$ \\
\hline Bentonite & $\begin{array}{l}25-500 \\
\mathrm{mg} \mathrm{ml}^{-1}\end{array}$ & $5-11$ & $0-3000$ & 2.5 & 5 & 2.5 & 20 & 360 & 73 & 0.18 & $R^{2}=0.90$ & $R^{2}=0.98$ & (Banat et al., 2000) \\
\hline $\begin{array}{l}\text { Funaliatrogii } \\
\text { pellets }\end{array}$ & $30-600$ & $2-11$ & 3000 & $\begin{array}{c}0.25 \text { and } \\
2.0\end{array}$ & 8 & 2 & 25 & 360 & 80 & - & $R^{2}=0.97$ & $\mathrm{R}^{2}=0.99$ & $\begin{array}{l}\text { (Bayramoglu et al., } \\
\text { 2009) }\end{array}$ \\
\hline $\begin{array}{c}\text { porous } \\
\text { hydroxyapatite } \\
\text { (PHAp) } \\
\end{array}$ & $0-100$ & $2-12$ & 180 & 20 & 6 & 20 & 25 & 60 & - & $8.2 \pm 0.4$ & $R^{2}>0.99$ & - & \multirow{3}{*}{ (Bahdod et al., 2009) } \\
\hline $\begin{array}{c}\text { crystalline } \\
\text { hydroxyl } \\
\text { apatite(HAp) }\end{array}$ & $0-100$ & $2-12$ & 180 & 20 & 6 & 20 & 25 & 120 & - & $3.9 \pm 0.2$ & $R^{2}>0.99$ & - & \\
\hline $\begin{array}{l}\text { fluoroapatite } \\
\text { (FAp) }\end{array}$ & $0-100$ & $2-12$ & $3 \mathrm{~h}$ & 20 & 6 & 20 & 25 & 120 & - & $3.1 \pm 0.2$ & $R^{2}>0.99$ & - & \\
\hline (BPC) & $\begin{array}{l}25-500 \\
\mathrm{mg} \mathrm{dm}\end{array}$ & $2-12$ & 120 & $0.5 \mathrm{~g} \mathrm{dm}^{-3}$ & 6 & - & 60 & 120 & 70 & 89.5 & $R^{2}=0.99$ & $R^{2}=0.98$ & (Dursun et al., 2005) \\
\hline $\begin{array}{c}\text { Black gram husk } \\
\text { (BGH) }\end{array}$ & 100 & $2-12$ & 1440 & $\begin{array}{c}\text { More than } \\
0.3 \\
\end{array}$ & 5.1 & 0.5 & $25 \pm 2$ & 360 & more than 95 & - & $R^{2}=0.94$ & $\mathrm{R}^{2}=0.95$ & \multirow{3}{*}{$\begin{array}{c}\text { (Srihari and Das, } \\
\text { 2008) }\end{array}$} \\
\hline $\begin{array}{c}\text { Green gram husk } \\
(\mathrm{GGH}),\end{array}$ & 100 & $2-12$ & 1440 & $\begin{array}{c}\text { More than } \\
0.35 \\
\end{array}$ & 5.1 & 0.5 & $25 \pm 2$ & 360 & more than 95 & - & $R^{2}=0.88$ & $\mathrm{R}^{2}=0.95$ & \\
\hline Rice husk (RH) & 100 & $2-12$ & 1440 & $\begin{array}{c}\text { More than } \\
0.4\end{array}$ & 5.1 & 0.5 & $25 \pm 2$ & 360 & more than 95 & - & $\mathrm{R}^{2}=0.95$ & $\mathrm{R}^{2}=0.95$ & \\
\hline (TNSAC) & $25-200$ & $2-10$ & $0-80$ & $2,5,10$ & 4 & 5 & $25 \pm 2$ & - & 78 & - & $R^{2}=0.99$ & $\mathrm{R}^{2}=0.99$ & (Goud et al., 2005) \\
\hline (RHA-300) & $10-300$ & $1-13$ & $0-480$ & $1-10$ & 5 & $1 \mathrm{gr} / 100 \mathrm{ml}$ & $21 \pm 2$ & 300 & - & 0.951 & $R^{2}=0.97$ & $\mathrm{R}^{2}=0.98$ & \multirow{4}{*}{ (Kermani et al., 2006) } \\
\hline (RHA-400) & $10-300$ & $1-13$ & $0-480$ & $1-10$ & 5 & $1 \mathrm{gr} / 100 \mathrm{ml}$ & $21 \pm 2$ & 300 & - & 1 & $\mathrm{R}^{2}=0.98$ & $\mathrm{R}^{2}=0.97$ & \\
\hline (RHA-500) & $10-300$ & $1-13$ & $0-480$ & $1-10$ & 5 & $1 \mathrm{gr} / 100 \mathrm{ml}$ & $21 \pm 2$ & 300 & - & 0.989 & $R^{2}=0.97$ & $\mathrm{R}^{2}=0.96$ & \\
\hline$(\mathrm{GAC})$ & $10-300$ & $1-13$ & $0-480$ & $1-10$ & 5 & $1 \mathrm{gr} / 100 \mathrm{ml}$ & $21 \pm 2$ & 300 & - & 1 & $R^{2}=0.99$ & $\mathrm{R}^{2}=0.88$ & \\
\hline Jute Stick & $10-60$ & $6-12$ & $50-400$ & $0.5-4$ & 10 & 3 & $25-40$ & 300 & 68 & - & - & - & (Mustafa et al., 2008) \\
\hline $\begin{array}{l}\text { Activated } \\
\text { Red Mud }\end{array}$ & 40 to 80 & $3-11$ & $5-60$ & $2-10$ & 7 & 6 & $25 \pm 2$ & 60 & 90.4 & - & $\mathrm{R}^{2}=0.99$ & $R^{2}=0.87$ & (Siboni et al., 2013) \\
\hline Sawdust & $100-500$ & $3-9$ & $20-180$ & $0.1-1$ & 6.7 & 0.82 & $30 \pm 1$ & 120 & 91.6 & - & $\mathrm{R}^{2}=0.99$ & $R^{2}=0.99$ & (Dakhil, 2013) \\
\hline $\begin{array}{c}\text { Saccharomyces } \\
\text { cerevisiae }\end{array}$ & $10-160$ & $1-12$ & $1-360$ & $0.3-10$ & 1 & 0.3 & $27 \pm 2$ & 240 & - & 30 & $R^{2}=0.99$ & $R^{2}=0.99$ & (Moyo et al., 2012) \\
\hline
\end{tabular}




\begin{tabular}{|c|c|c|c|c|c|c|c|c|c|c|c|c|c|}
\hline Sodium zeolite & $100-500$ & $3-9$ & $10-60$ & $0.8-5.2$ & 5 & 1 & $25 \pm 2$ & 40 & 100 & 13.051 & $R^{2}=0.94$ & $R^{2}=0.99$ & $\begin{array}{c}\text { (Saravanakumar and } \\
\text { kumar, 2013) }\end{array}$ \\
\hline $\begin{array}{l}\text { Colocasia } \\
\text { esculenta }\end{array}$ & $10-60$ & $2-12$ & 120 & 1 & 2 & 1 & 25 & 40 & - & 536.14 & $R^{2}=0.90$ & $R^{2}=0.99$ & $\begin{array}{c}\text { (Obi and Woke, } \\
\text { 2014) }\end{array}$ \\
\hline Wheat husk & $0.1-0.9$ & $3-11$ & $30-180$ & $1-9$ & $3-5$ & 3 & $25 \pm 2$ & 300 & 91.7 & - & $R^{2}=0.92$ & $R^{2}=0.90$ & $\begin{array}{c}\text { (Jagwani and Joshi, } \\
\text { 2014) }\end{array}$ \\
\hline $\begin{array}{c}\text { Typha orientalis } \\
\text { Presl }\end{array}$ & $50-150$ & $2-11$ & $0-200$ & $0.1-8$ & 5 & 14.30 & $20-30$ & 135 & - & - & $R^{2}=0.96$ & $\mathrm{R}^{2}=0.62$ & (Feng et al., 2015) \\
\hline
\end{tabular}


Table 2. Thermodynamic parameters in the adsorption process of phenol and phenolic compounds from aqueous environments

\begin{tabular}{|c|c|c|c|c|c|c|c|c|c|}
\hline Temperature ( $\left.{ }^{\circ} \mathrm{K}\right)$ & $\Delta \mathrm{G}^{0}\left(\mathrm{~kJ} \mathrm{~mol}^{-1}\right)$ & $\Delta \mathrm{H}^{0}\left(\mathrm{~kJ} \mathrm{~mol}^{-1}\right)$ & $\Delta \mathrm{S}^{0}\left(\mathrm{~J} \mathrm{~mol}^{-1} \mathrm{~K}^{-1}\right)$ & Spontaneous & Non Spontaneous & Endothermic & Exothermic & Physical/chemical & References \\
\hline 298 & -20.36 & -16.4 & 13.31 & \multirow{4}{*}{$\bullet$} & \multirow{4}{*}{-} & \multirow{4}{*}{-} & \multirow{4}{*}{$\bullet$} & \multirow{4}{*}{ Physical } & \multirow{4}{*}{ (Rodrigues et al., 2011) } \\
\hline 308 & -20.54 & & & & & & & & \\
\hline 318 & -20.57 & & & & & & & & \\
\hline 328 & -20.80 & & & & & & & & \\
\hline 296 & 3.293 & -1.666 & 5.510 & \multirow{4}{*}{-} & \multirow{4}{*}{-} & \multirow{4}{*}{-} & \multirow{4}{*}{$\bullet$} & \multirow{4}{*}{ Physical } & \multirow{4}{*}{ (Djebbar et al., 2012) } \\
\hline 200 & 0.250 & -1.000 & $\left(\mathrm{~J} \mathrm{~K}^{-1} \mathrm{~mole}^{-1}\right)$ & & & & & & \\
\hline 301 & -3.311 & & & & & & & & \\
\hline 306 & -3.340 & & & & & & & & \\
\hline 303 & -2.316 & $\begin{array}{c}2.4112 \\
\left(\mathrm{kcal} \mathrm{mol}^{-1}\right)\end{array}$ & $\begin{array}{c}15.60 \\
\left(\mathrm{cal} \mathrm{mol}^{-1} \text { ) }\right.\end{array}$ & \multirow{3}{*}{$\bullet$} & \multirow{3}{*}{-} & \multirow{3}{*}{$\bullet$} & & \multirow{3}{*}{ Physical } & \multirow{3}{*}{ (Nayak and Singh, 2007) } \\
\hline 313 & -2.472 & & & & & & & & \\
\hline 323 & $\begin{array}{c}-2.670 \\
\left(\mathrm{kcal} \mathrm{mol}^{-1}\right)\end{array}$ & & & & & & & & \\
\hline & -1.866 & & -126.47 & \multirow{5}{*}{$\bullet$} & \multirow{5}{*}{-} & \multirow{5}{*}{-} & \multirow{5}{*}{$\bullet$} & \multirow{5}{*}{ Physical } & \multirow{5}{*}{ (Abdelwahab and Amin, 2013) } \\
\hline 293 & -1.866 & -32.149 & $\left(\mathrm{~J} \mathrm{~mol}^{-1}\right)$ & & & & & & \\
\hline 303 & -0.666 & & & & & & & & \\
\hline 313 & -0.515 & & & & & & & & \\
\hline 323 & -0.102 & & & & & & & & \\
\hline 313 & 20.87 & 31.785 & 190.0 & \multirow{3}{*}{$\bullet$} & \multirow{3}{*}{-} & \multirow{3}{*}{$\bullet$} & \multirow{3}{*}{-} & \multirow{3}{*}{-} & \\
\hline 296 & 24.43 & & & & & & & & (Cherifi et al., 2009) \\
\hline 303 & 25.82 & & & & & & & & \\
\hline 298 & -8.58 & -10.16 & -5.3 & & & & & & \\
\hline 308 & -8.53 & & & & - & - & - & & \\
\hline 318 & -8.48 & & & $\bullet$ & - & - & $\bullet$ & Pnysical & (Rusnal et al., ¿U11) \\
\hline 328 & -8.42 & & & & & & & & \\
\hline 273 & -0.83 & -6.70 & -21.96 & & & & & & \\
\hline 283 & -0.59 & & & & & & & & \\
\hline 293 & -0.37 & & & $\bullet$ & - & - & $\bullet$ & - & (Senturk et al., 2009) \\
\hline 303 & -0.19 & & & & & & & & \\
\hline 313 & 0.05 & & & & & & & & \\
\hline 303 & -5.535 & -26.442 & -69.0 & & & & & & \\
\hline 313 & -4.845 & & & $\bullet$ & - & - & $\bullet$ & - & (Aravindhan et al., 2009) \\
\hline 323 & -4.155 & & & & & & & & \\
\hline
\end{tabular}

